\title{
PENGEMBANGAN DAN PEMBUATAN PROTOTYPE DISPENSER UNTUK KESEHATAN DENGAN PENDEKATAN ERGONOMI
}

\author{
Lithrone Laricha Salomon ${ }^{1)}$, Wilson Kosasih ${ }^{1)}$, Rickoo ${ }^{2)}$, Alvan Prayogo ${ }^{2)}$, Joses Julius ${ }^{2)}$ \\ ${ }^{1)}$ Staf Pengajar Program Studi Teknik Industri Universitas Tarumanagara \\ ${ }^{2)}$ Mahasiswa Program Studi Teknik Industri Universitas Tarumanagara \\ e-mail: lithrones@ft.untar.ac.id; rickoexetera1705@gmail.com
}

\begin{abstract}
ABSTRAK
Perancangan dan pengembangan produk dilakukan guna memberi nilai tambah pada suatu produk. Produk yang dikembangkan pada penelitian ini adalah dispenser air. Penelitian ini didasari oleh kesadaran atas pentingnya mengonsumsi obat secara teratur, dengan dosis yang sesuai, dan tepat waktu. Penelitian dilakuan melalui beberapa tahapan, di antaranya: tinjauan pustaka, perancangan desain, pembuatan prototype, dan uji coba prototype. Dispenser ini dilengkapi dengan kotak obat dan alarm. Produk yang dikembangkan ini didesain menggunakan Software Autodesk Inventor. Dispenser dibuat dari material besi yang disambung dengan proses pengelasan, sedangkan kotak obat yang telah dirancang tersebut dibuat menggunakan proses additive manufacturing. Proses desain produk didasari atas perhitungan data antropometri masyarakat Indonesia dengan pendekatan ergonomi. Hasil dari penelitian ini adalah berupa prototype yang telah diuji coba dan dan dapat menjalankan fungsinya sesuai dengan ukuran dimensi yang telah mengacu pada tabel antropometri.
\end{abstract}

Kata kunci: Perancangan dan Pengembangan Produk, Additive Manufacturing, Ergonomi, Antropometri.

\begin{abstract}
Product design and development is done to provide added value to a product. The product developed in this study is a water dispenser. This research is based on awareness of the importance of taking medication regularly, in the right dosage, and being on time to consume the medicines. The research was carried out through several stages, including: literature study, design making, prototype making, prototype testing. This dispenser is equipped with a medicine box and alarm. The product is designed using Autodesk Inventor software. The dispenser is made of iron which was assembled by welding process, while the medicine boxes were made by additive manufacturing. The product design process is based on the calculation of anthropometric data of the Indonesian people with an ergonomic approach. The result of this research is a prototype that has been tested and can carry out its functions according to the dimensions that have been referred to in the anthropometric table.
\end{abstract}

Keywords: Product Design and Development, Additive Manufacturing, Ergonomic, Anthropometric.

\section{PENDAHULUAN}

Kesehatan merupakan anugerah yang begitu luar biasa dari yang maha kuasa, namun ada kalanya seseorang dapat terkena sebuah penyakit, karena sakit merupakan suatu fenomena yang tidak terlepaskan dalam kehidupan didunia ini. Sakit yang diderita oleh seseorang tersebut akan menimbulkan rasa tidak nyaman bagi penderitanya sehinga akan dilakukan upaya-upaya penyembuhan yang salah satunya adalah mengkonsumsi obatobatan, namun dari hasil wawancara yang kami dapatkan oleh beberapa narasumber dan orang-orang sekitar mereka pernah lupa untuk mengkonsumsi obat yang harus mereka minum karena kesibukan aktivitas lain, padahal ketidak teraturan konsumsi obat-obatan dapat menimbulkan efek samping seperti multidrug-resistant.

Multidrug-resistant (MDR) adalah suatu keadaan di mana bakteri resisten terhadap minimal satu jenis antibiotik dari $\geq 3$ golongan antibiotik [1]. Banyak faktor yang memberikan kontribusi terhadap resistensi obat pada negara berkembang termasuk ketidaktahuan penderita tentang penyakitnya, kepatuhan penderita, pemberian monoterapi atau regimen obat yang tidak efektif, dosis tidak adekuat, instruksi yang buruk, keteraturan 
berobat yang rendah, motivasi penderita kurang, suplai obat yang tidak teratur, bioavailability yang buruk, dan kualitas obat memberikan kontribusi terjadinya resistensi obat sekunder [2].

Pengembangan produk dispenser ini bertujuan untuk meningkatkan kedisplinan dan kepatuhan masyarakat dalam mengonsumsi obat-obatan secara rutin dan tepat waktu sesuai dengan dosis yang telah ditentukan untuk mengurangi kemungkinan terjadinya multi drug resistant. Memasuki Era Revolusi Industri ke-4 atau yang biasa disebut dengan istilah Industry 4.0, dimana industri mengalami pengembangan yang pesat terutama di bidang manufaktur. Desain suatu produk menjadi sangat penting mengingat begitu ketatnya persaingan dan cepatnya inovasi yang dikeluarkan oleh produsen untuk mendapatkan pasar penjualan [3], maka 3D printing digunakan untuk proses pencetakan salah satu komponen.

\section{TINJAUAN PUSTAKA}

\section{Perancangan dan Pengembangan Produk}

Perancangan atau merancang merupakan suatu usaha untuk menyusun dan menciptakan hal-hal baru yang bermanfaat bagi kehidupan manusia. Dalam hal ini, merancang dapat berarti benar-benar baru atau pengembangan produk yang sudah ada, sehingga mendapatkan peningkatan kinerja dari produk tersebut. Pengembangan produk merupakan serangkaian aktivitas yang dimulai dari analisis persepsi dan peluang pasar, kemudian diakhiri dengan tahap produksi penjualan dan pengiriman produk ke konsumen [4].

\section{Ergonomi}

Istilah ergonomi berasal dari bahasa latin yaitu ergon yang berarti kerja dan nomos yang berarti hukum alam dan dapat didefinisikan sebagai studi tentang aspek-aspek manusia dalam lingkungan yang ditinjau secara anatomi, fisiologi, psikologi, engineering, manajemen dan desain atau perancangan [5]. Ergonomi adalah suatu cabang ilmu yang sistematis untuk memanfaatkan informasi-informasi mengenai sifat, kemampuan dan keterbatasan manusia untuk merancang suatu sistem kerja sehingga orang dapat hidup dan bekerja pada sistem itu dengan baik, yaitu mencapai tujuan yang diinginkan melalui pekerjaan itu dengan efektif, aman, dan nyaman [6].

\section{Antropometri}

Menurut Sutalaksana, antropometri adalah pengetahuan yang menyangkut pengukuran tubuh manusia khususnya dimensi tubuh [6]. Berikut ini merupakan data antropometri masyarakat Indonesia (Tabel 1):

Tabel 1. Data Antropometri Masyarakat Indonesia

\begin{tabular}{clcccc}
\hline \multirow{2}{*}{ No } & \multirow{2}{*}{ Dimensi Tubuh } & \multicolumn{4}{c}{ Persentil (cm) } \\
\cline { 3 - 6 } & & $\mathbf{5}^{\text {th }}$ & $\mathbf{5 0}^{\text {th }}$ & $\mathbf{9 5}^{\text {th }}$ & SD \\
\hline 1 & Tinggi Tubuh & 142.36 & 163.28 & 184.2 & 12.72 \\
2 & Tinggi Mata & 138.65 & 153.45 & 168.25 & 9 \\
3 & Tinggi Bahu & 123.59 & 136.75 & 149.91 & 8 \\
4 & Tinggi Siku & 91.71 & 102.69 & 113.67 & 6.68 \\
\hline
\end{tabular}

\section{D Printing}

3D printing adalah salah satu bentuk dari additive manufacturing dimana sebuah objek tiga dimensi dibentuk dengan menambahkan material layer demi layer [7]. Langkah awal dari $3 D$ printing adalah membuat model digital dari objek yang akan dicetak. 
Pembuatan model digital ini biasanya menggunakan software Computer-Assisted Design (CAD) atau menggunakan pelayanan online yang telah disediakan dari platform $3 D$ printing. $3 D$ scanner juga dapat digunakan secara otomatis untuk membuat model dari objek eksis (seperti 2D scanner). Di samping 3D scanner yang harganya masih tergolong mahal (\$949), aplikasi smartphone juga dapat digunakan untuk membuat model $3 D$ seperti Autodesk 123D Catch [7]. 3D printing memiliki keuntungan dan potensi yang besar. Dengan 3D printing ini bisa dibuat berbagai macam barang dengan bentuk geometri bebas dan kompleks tanpa kendala keterbatasan proses manufaktur [8].

\section{METODE PENELITIAN}

Tahapan yang dilakukan dalam perancangan ini dapat dilihat pada Gambar 1. dimana penelitian ini diawali dengan studi literatur dan riset awal dilanjutkan dengan pembuatan desain 3D untuk prototype, diikuti dengan membuat rangkaian komponen elektrik dan melakukan pengujian apakah komponen dapat berfungsi dengan baik.

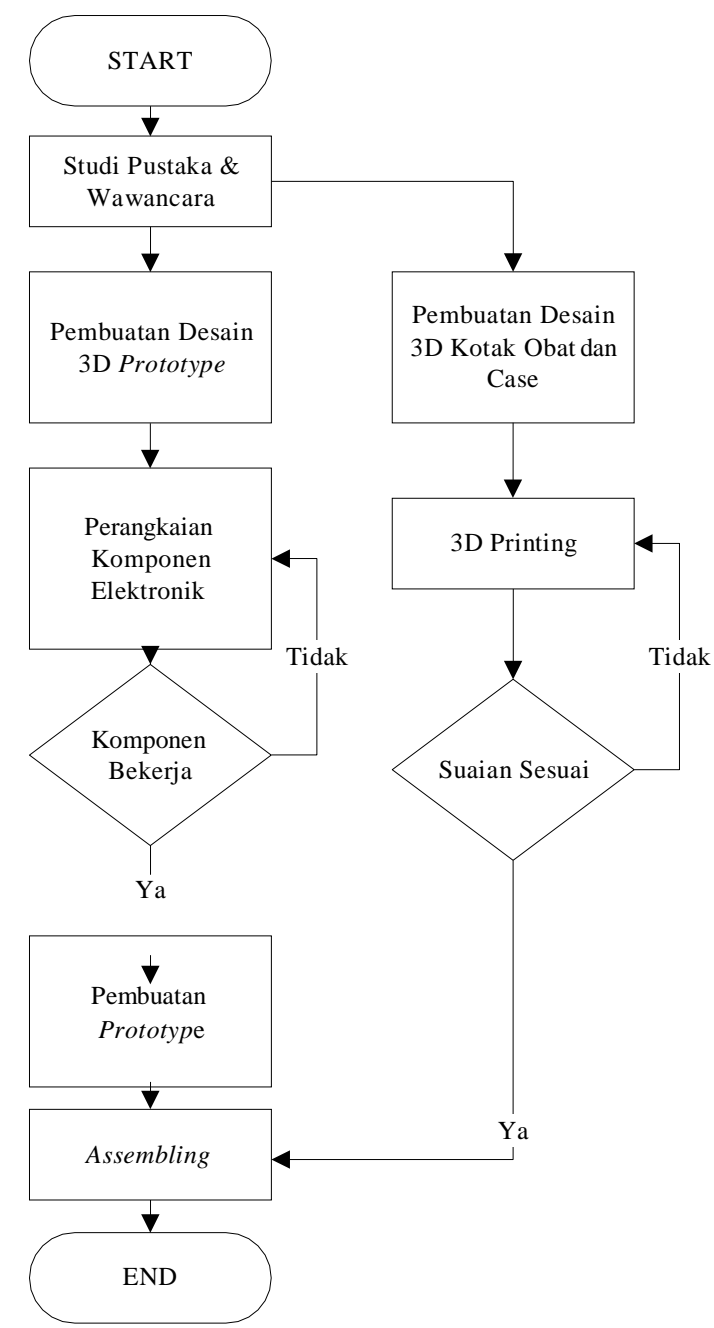

Gambar 1. Diagram Alir Metode Penelitian

Proses pembuatan prototype dibagi menjadi 2 tahapan yaitu proses pembuatan desain dan pembuatan prototype, pembuatan desain secara keseluruhan menggunakan Software Autodesk Inventor. Dalam proses pembuatan prototype untuk kotak obat dilakukan menggunakan 3D Printer untuk bagian kotak obat dan proses perbengkelan untuk kerangka yang akan digunakan untuk prototype ini. 


\section{HASIL DAN PEMBAHASAN}

\section{Dimensi Rancangan}

Mengacu pada tabel antropometri untuk masyarakat Indonesia, maka ukuran yang digunakan untuk prototype produk ini dapat dilihat pada Tabel 2.

Tabel 2. Dimensi Produk

\begin{tabular}{clccccc}
\hline No & \multicolumn{1}{c}{ Dimensi Produk } & Acuan & Persentil & $\begin{array}{c}\text { Ukuran } \\
\text { (cm) }\end{array}$ & $\begin{array}{c}\text { Kelonggaran } \\
\text { (cm) }\end{array}$ & $\begin{array}{c}\text { Hasil } \\
\text { (cm) }\end{array}$ \\
\hline 1 & Tinggi dispenser & Tinggi tubuh & $5 \%$ & 142.36 & -2.36 & 140 \\
2 & Tinggi jam dan alarm & Tinggi mata & $5 \%$ & 138.65 & -3.65 & 135 \\
3 & Tinggi maksimum kotak obat & Tinggi bahu & $5 \%$ & 123.59 & -3.59 & 120 \\
4 & $\begin{array}{l}\text { Tinggi minimum kotak obat, } \\
\text { tinggi tempat gelas }\end{array}$ & Tinggi siku & $5 \%$ & 91.71 & -1.71 & 90 \\
\hline
\end{tabular}

\section{Desain Rancangan 3D}

Perancangan desain 3D Kotak Obat Dilengkapi Dispenser menggunakan software Autodesk Inventor 2018, di mana rancangan desain dibuat dengan mempertimbangkan data antropometri yang dihitung seperti tertera pada Tabel 2 untuk menghasilkan produk yang ergonomis.

Dalam proses perancangan, terdapat beberapa komponen yang dimiliki oleh prototipe ini, yaitu: kotak obat, case kotak obat, pintu, case dispenser, modul display LCD 16x2, push button, motor pompa air, buzzer, plat badan dan rangka badan. Komponen tersebut dirancang dalam model 3D masing-masing kemudian digabungkan atau dirakit menjadi satu sehingga menjadi bentuk akhir. Berikut ini adalah Gambar 2 dan Gambar 3 rancangan desain untuk bagian kerangka prototype:

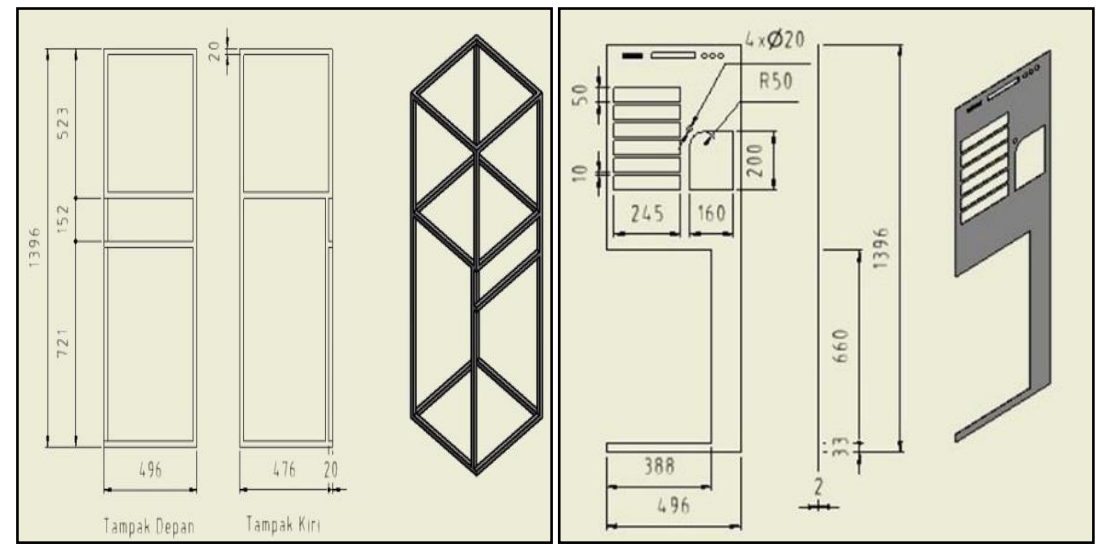

Gambar 2. Rancangan Kerangka Untuk Perbengkelan

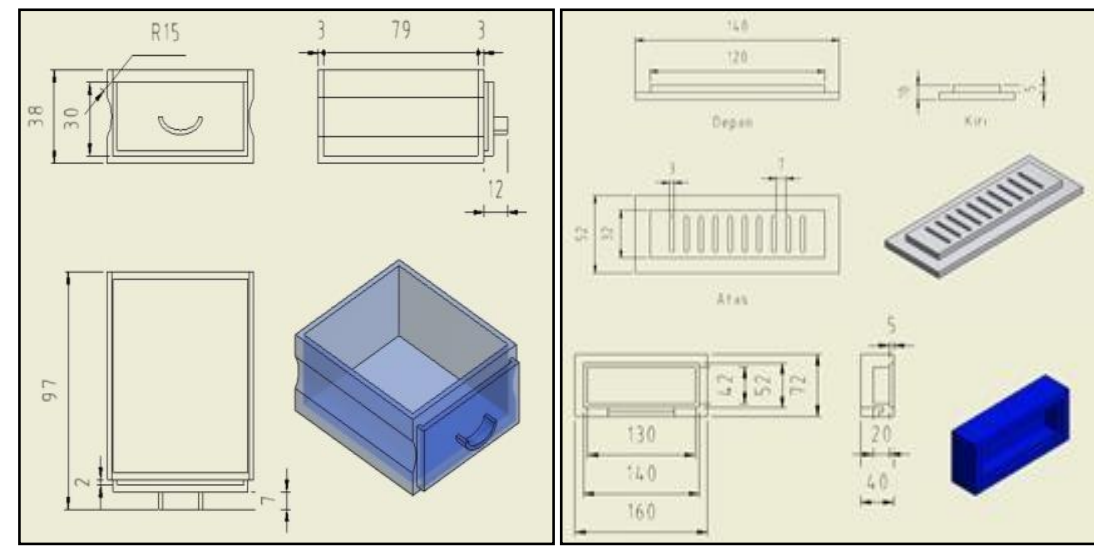

Gambar 3. Rancangan Kotak Untuk 3D Printing 


\section{Pembuatan Prototype}

Dalam proses pembuatan rangka dan badan dari dispenser dilakukan beberapa tahapan. Tahapan pertama adalah pengukuran dan pemotongan bahan-bahan seperti plat besi, batang hollow steel, dan akrilik untuk pintu. Setelah semua bahan sudah dipotong dan dimensinya sudah sesuai dengan desain, maka langkah selanjutnya adalah penyusunan dan penyambungan rangka badan dengan mengelas batang hollow steel. Setelah rangka sudah tersusun dan tersambung, berikutnya case dispenser disambungkan pada rangka juga dengan pengelasan. Teknik pengelasan yang digunakan adalah las argon. Berikutnya, pemasangan pintu yang disambungkan dengan engsel yang diakhiri dengan proses pengecatan (Gambar 4).

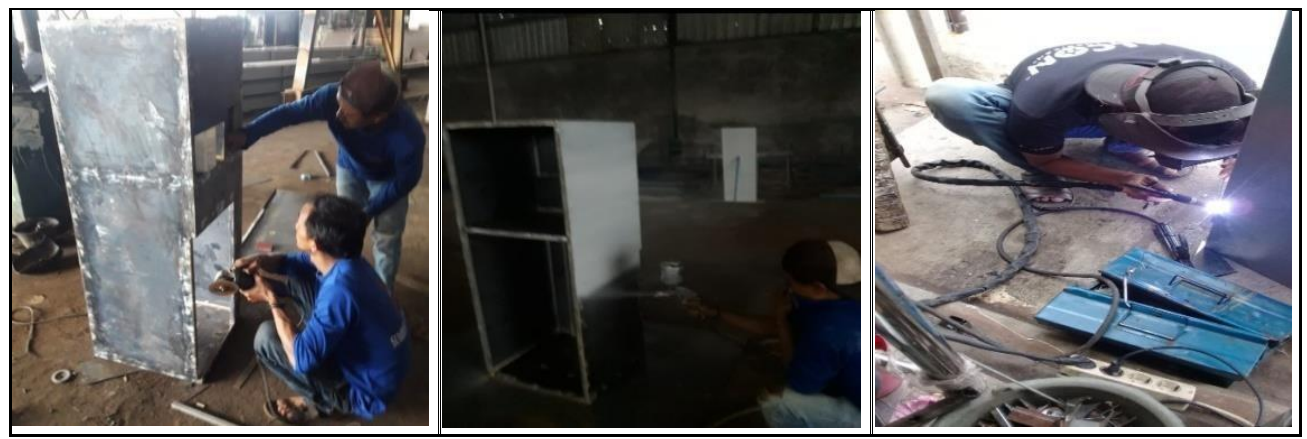

Gambar 4. Proses Perbengkelan

Berbeda dengan proses pembuatan rangka dan badan dispenser, proses pembuatan kotak obat dilakukan menggunakan additive manufacturing atau 3D Printing. Pembuatan kotak obat dengan $3 D$ printing ini menggunakan material bahan filamen PLA (Gambar 5).

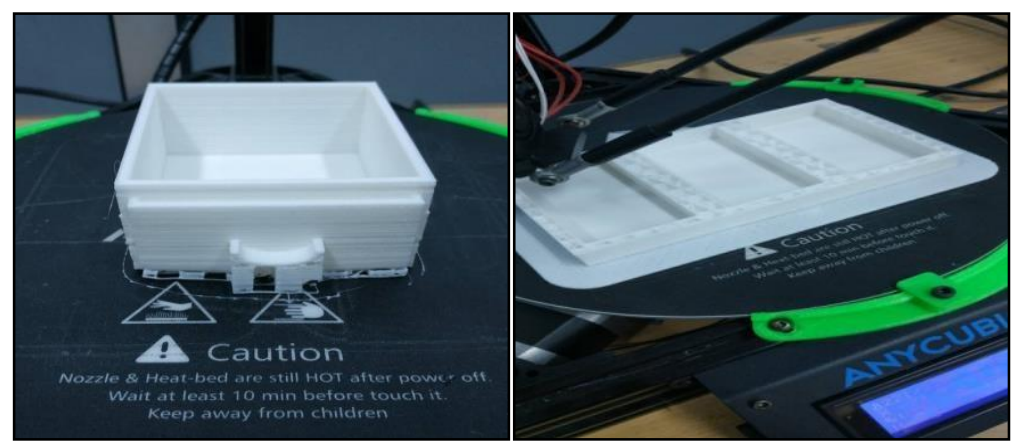

Gambar 5. Proses 3D Printing

\section{Hasil Akhir dan Pengujian Prototype}

Setelah seluruh komponen telah selesai dibuat maka dilakukan proses assembling antara komponen pada rangka yang sudah dibuat sesuai dengan desain yang telah dibuat yang dapat dilihat pada Gambar 6.

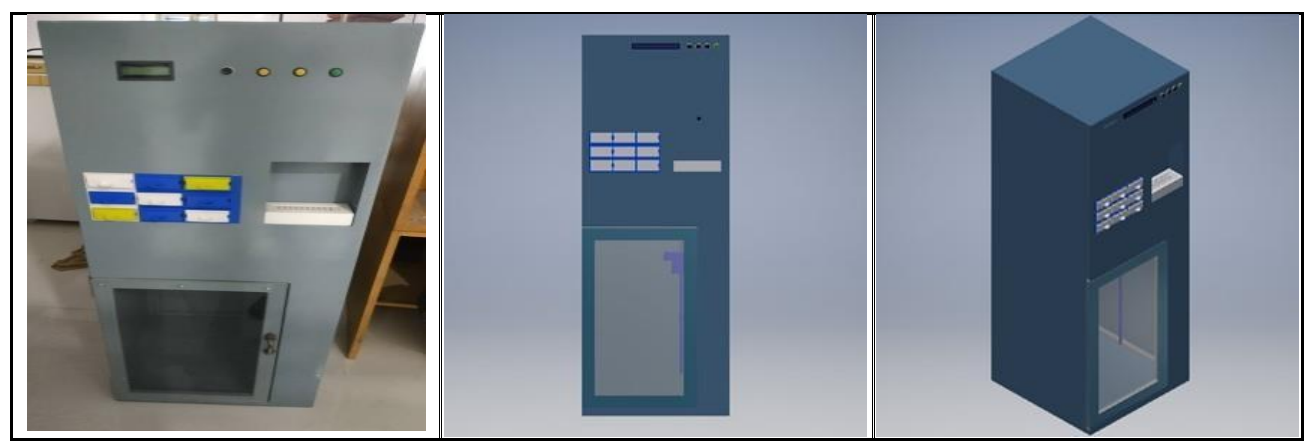

Gambar 6. Prototype Dispenser 
Dalam pengujian teknis untuk prototype Kotak Obat dilengkapi Dispenser (Gambar 7), pengujian dinyatakan berhasil karena berhasil dalam menampilkan waktu dan tanggal secara real time, pengeluaran air dari selang yang bersumber dari galon air hingga menuju dip tray dan penyimpanan obat-obatan pada kotak obat.

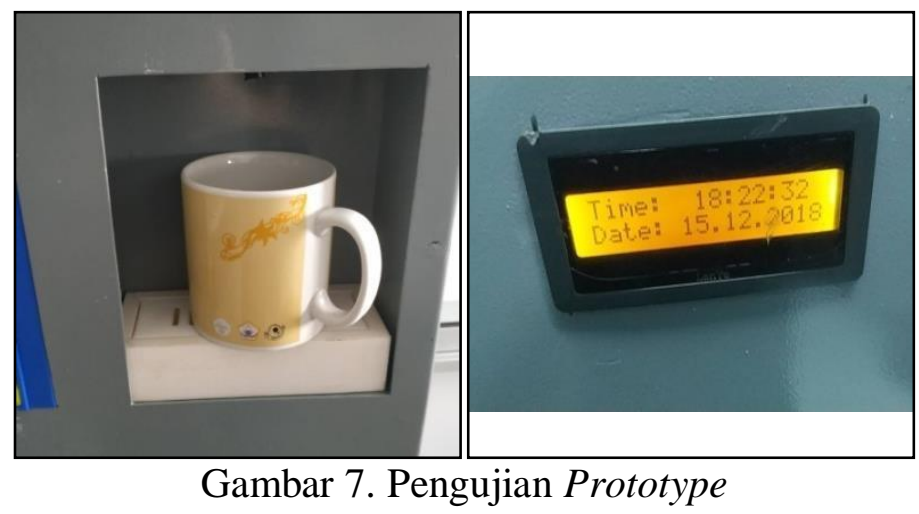

\section{KESIMPULAN}

Produk didesain dengan mengacu pada data antropometri masyarakat Indonesia, sehingga menghasilkan produk yang ergonomis. Setelah melewati proses perancangan desain 3D produk menggunakan Software Autodesk Inventor, protoype dibuat melalui beragam proses produksi. Rangka dispenser terbuat dari batang besi hollow kemudian disambungkan dengan badan dispenser yang terbuat dari plat besi melalui proses pengelasan. Proses pembuatan kotak obat dilakukan menggunakan Additive Manufacturing atau 3D Printing menggunakan material filamen PLA. Prototype telah melewati proses uji coba dan dapat menjalankan fungsi sebagaimana produk ini dirancang dan harapannya dengan desain dispenser yang telah dibuat ini dapat meningkatkan kedisplinan masyarakat dalam menkonsumsi obat-obatannya. Dalam upaya pengembangan produk supaya menjadi semakin baik, disarankan agar material casing dispenser yang semula adalah besi sebaiknya diganti dengan plastik, baik itu PP maupun ABS.

\section{DAFTAR PUSTAKA}

[1]. Magiokaros, A.-P., Srinivasan, A., Carey, R.B., Carmeli, Y., Falagas, M.E., and Giske, C.G., 2012, Multidrug-resistant, extensively drug-resistant and pandrug-resistant bacteria: an international expert proposal for interin standard definitions for acquired resistance. Clinical Microbiology and Infection 18:268-281

[2]. Masniari, L., Priyanti, Z.S., dan Tjandra, Y.A., 2007, Faktor-Faktor Yang Mempengaruhi Kesembuhan Penderita TB Paru. J Respir Indo. 27:176-183

[3]. Sumantri, Dede.,2012, Peningkatan Kinerja Mesin Rapid Prototyping Berbasis Fused Desposition Modelling. Skripsi. Jakarta: Universitas Indonesia.

[4]. Irawan, A.P., 2017, Perancangan \& Pengembangan Produk Manufaktur, ANDI, Yogyakarta, Halaman 3.

[5]. Nurmianto, Eko. Ergonomi, 2008, Konsep Dasar dan Aplikasinya. Surabaya: Teknik Industri-ITS.

[6]. Sutalaksana, Iftikar Z., 1979, Teknik Tata Cara Kerja. Bandung, Institut Teknologi Bandung.

[7]. Rayna, T., Striukova, L., 2016, From rapid prototyping to home fabrication: How 3D printing is changing business model innovation, Technological Forecasting and Social Change, Vol. 102, $214-224$.

[8]. Gebler, M., Schoot U, A.J.M., and Visser, C., 2014, A global sustainability perspective on 3D printing technologies, Energy Policy, Vol.74, 158-167. 